\title{
Production of pigments by Rhodotorula mucilaginosa
}

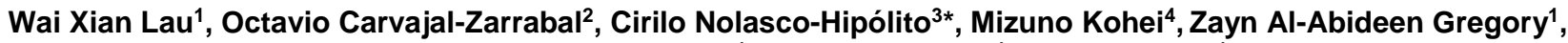 \\ Mohammad Omar Abdullah¹, Seng Chiew Toh', Samuel Lihan'1
}

${ }^{1}$ Faculty of Resource Science and Technology, Universiti Malaysia Sarawak, 94300 Kota Samarahan, Sarawak, Malaysia.

${ }^{2}$ Biochemical and Nutrition Chemistry Area, University of Veracruz, SS Juan Pablo II s/n, Boca del Río, CP 94294 Veracruz, México.

${ }^{3}$ Faculty of Engineering. Universiti Malaysia Sarawak, 94300 Kota Samarahan, Sarawak, Malaysia.

${ }^{4}$ Department of Materials Science and Chemical Engineering, Kitakyushu National College of Technology, 5-20-1 Shii, Kokura Minami-ku, Kitakyushu 802-0985, Japan.

Email: hcnolasco@unimas.my

\begin{abstract}
Aims: Pigments have a large and growing market in the world. Drawbacks in their production such as raw materials availability and low productivity prompt the search for fermentation routes for industrial production. A carotenoidproducing yeast identified as Rhodotorula mucilaginosa was isolated in our laboratory. The aim of this study was to investigate the growth and carotenoid production capacity of the yeast.

Methodology and results: A cost-effective substrate of sago starch hydrolysate (SSH) derived from sago fiber waste was used for the fermentation. The fermentation was carried out for $96 \mathrm{~h}$ at $27^{\circ} \mathrm{C}$ in batch mode. The biomass produced during 5 days of fermentation was $9.6 \mathrm{~g} / \mathrm{L}$, which contained a carotenoid concentration of $8.1 \mathrm{mg} / \mathrm{L}$ and a specific yield of $845.9 \mu \mathrm{g} / \mathrm{g}$.
\end{abstract}

Conclusion, significance and impact of study: The results demonstrated the capacity of $R$. mucilaginosa yeast to produce carotenoids and its potential for larger-scale production.

Keywords: Rhodotorula, carotene, torularhodin, torulene, sago starch hydrolysate

\section{INTRODUCTION}

The colourful splendour of nature is mainly due to the presence of compounds like carotenoids, anthocyanins, porphyrins, and chlorophylls. Carotenoids have high impact in nature since they are responsible for many of the brilliant red, orange, and yellow colours in plants and animals. The paramount interest in using microbial pigments is because of their natural character, safety, and medicinal properties, and their ability to provide controllable and predictable yields (Joshi et al., 2003). Carotenoids produced by the microbial route are very significant due to seasonal and geographic variability in the marketing and production of some pigments of plant origin (Frenova and Beshkova, 2009). Microbial processes are low-cost, with the use of natural carbohydrate sources as substrate bringing economic advantages. Carotenoids are synthesized by many microorganisms and plants in nature with acetyl-CoA being the key precursor during carotenoid biosynthesis (Olson, 1964; Moise et al., 2014). The production of carotenes such as Torularhodin and Torulene by the yeast Rhodotorula mucilaginosa ( $R$. mucilaginosa) has been demonstrated previously (Aksu and Eren, 2005;
Irazusta et al., 2013; Cheng and Yang, 2016; Yen et al., 2016; Yoo et al., 2016). While use of this yeast is currently limited due to the prohibitive cost of production, it remains of interest since carotenoids have high demand and price in the market. The market value of $\beta$-carotene, estimated at around $\$ 250$ million in 2007 , increased to nearly $\$ 261$ million in 2010 . This market is expected to grow to $\$ 334$ million by 2018 at a compound annual growth rate of $3.1 \%$. Lutein was around $\$ 233$ million in 2010 and is expected to reach $\$ 309$ million by 2018 with a compound annual growth rate of $3.6 \%$ (McWilliams, 2011). In the fermentation industry, the market is affected by the availability of the raw materials to produce the desired products. In the case of carotenoids, diverse raw materials have been tested to decrease the production cost and at the same time to maintain or even increase the productivity (Cheng and Yang, 2016). The consensus is that the production cost could be reduced when the yield of the product is increased, and a less expensive substrate is utilized. Fermentation parameters have a strong influence on productivity, and control of production facilitates the extraction of intracellular carotenoids from yeast (Yoo et al., 2016). To reduce the production cost, efforts to use cost-effective substrates such as food waste 
or agricultural wastes have been reported. The use of agricultural wastes such as glucose, molasses sucrose, and whey lactose sugars as the carbon sources also have been reported (Aksu and Eren, 2005; Cheng and Yang, 2016). On the other hand, since $R$. mucilaginosa can accumulate a large amount of lipids from the hydrolysate of cassava starch, Li et al. (2010) performed fermentation using seawater, with the aim to reduce the consumption of water ( $\mathrm{Li}$ et al., 2010). The direct cultivation of oleaginous $R$. mucilaginosa in a 5 - $\mathrm{L}$ airlift bioreactor using seawater instead of pure water led to a slightly lower biomass being achieved, at 17.2 compared to $18.1 \mathrm{~g} / \mathrm{L}$, respectively (Yen et al., 2016). The capacity of $R$. mucilaginosa to biodegrade chemical wastes such as the toxic pesticide diazinon also has been demonstrated (Pacia et al., 2016). The strain improved the production of pigments in the presence of this toxicant. In a similar approach, the relationship among carotenoid production, copper bioremediation and oxidative stress in $R$. mucilaginosa RCL-11 has been demonstrated as well (Irazusta et al., 2013). The characteristic of biodegradation of toxicants confers additional potential to the strain to be used in polluted soils. Regarding media composition in this study, we explore the use of sago fibres as a starch source from which to produce glucose as the substrate, since sago fibres are an industrial waste without price in the market. In our laboratory, we isolated a contaminating strain that grew in a very simple media. It was interesting because the media was the filtrate of a glucose syrup passed through a powdered activated charcoal filter. Not many nutrients were there; just the filtrate and some micronutrients. This is what the fermentation industry is looking for. Microorganisms without complex nutritional requirements are desirable. Upon cultivating the strain in agar plates and using the same simple media (filtrate syrup), the strain produced an orange pigment. It was identified as Rhodotorula mucilaginosa by molecular techniques (not the focus of this study).

\section{Starch from sago fibres}

Typical sago starch mill releases the wastewater containing residual starch and fibres in the nearby streams. Sago fibres are a starchy lignocellulosic byproduct in the production of sago flour. It is generated from the pith of Metroxylon sagu. In Malaysia, Sarawak is the largest sago-growing area and the biggest exporter of sago starch. Sago fibres on a dry basis contain $58 \%$ starch, $23 \%$ cellulose, $9.2 \%$ hemicellulose, and $4 \%$ lignin (Chew and Shim, 1993; Linggang et al., 2012; Lai et al., 2016). The dried-powder form of sago fibres has shown the ability to be converted into fermentable sugar via enzymatic hydrolysis or acid treatment. A total of $0.62 \mathrm{~g}$ of glucose per $1 \mathrm{~g}$ of fibres $(\mathrm{g} / \mathrm{g})$ can be produced by using sulphuric acid hydrolysis (Kumoro et al., 2008). The presence of a suitable carbon source is crucial for the synthesis of carotenoids. Rhodotorula has potential as a natural source of carotenoids. One alternative to find a cost-effective substrate is the use of glucose derived from the starch remaining in the sago fibres during the production of sago flour. Thus, the aim of this study was to assess the growth and production of carotenoids from $R$. mucilaginosa using hydrolysed sago starch (HSS) derived from sago fibres as a low-cost carbohydrate source.

\section{MATERIALS AND METHODS}

\section{Microorganism}

The strain of $R$. mucilaginosa used was a contaminant yeast strain locally isolated in a Universiti Malaysia Sarawak (UNIMAS) laboratory. Potato dextrose agar (PDA) was used to maintain the yeast culture. The culture was stored in a refrigerator at $4{ }^{\circ} \mathrm{C}$ after $30^{\circ} \mathrm{C}$ incubation for 24 to $72 \mathrm{~h}$. The purity of the culture was regularly checked. The yeast strain was activated weekly (Yehia et al., 2013).

\section{Maintaining media}

Potato Dextrose Agar (PDA) media (Difco, USA) was used for the isolation and cultivation of the yeast. All media used throughout this study were prepared according to manufacturer directions.

\section{Preparation of sago starch hydrolysate (SSH)}

Sago fibres were obtained from Herdsen Sago Mill in Sarawak, Malaysia. Prior to composition analysis, the sago fibre samples were oven dried at $90^{\circ} \mathrm{C}$ for $24 \mathrm{~h}$ before being ground to pass through a $1 \mathrm{~mm}$ sieve. Dried sago fibres were analysed for moisture content.

A suspension of sago fibres, $10 \%(\mathrm{w} / \mathrm{v})$ dry basis, was dissolved in distilled water. The $\mathrm{pH}$ of the suspension was adjusted to $\mathrm{pH}$ 6.5. Enzymatic hydrolysis was performed according to the directions of Novozymes A/C for starchy materials.

\section{Cultivation of yeast for carotenoid production Inoculum preparation}

A loop full of an active $(24 \mathrm{~h}) R$. mucilaginosa cultivated on PDA was transferred into a universal bottle containing $20 \mathrm{~mL}$ of a media consisting of $40 \mathrm{~g} / \mathrm{L}$ glucose and $5 \mathrm{~g} / \mathrm{L}$ yeast extract. The strain was incubated for $24 \mathrm{~h}$ at $36^{\circ} \mathrm{C}$. The activated strain was then transferred into $200 \mathrm{~mL}$ growth medium containing $8 \mathrm{~g}$ of glucose and $1 \mathrm{~g}$ of yeast extract. The cells were incubated for $12 \mathrm{~h}$ at room temperature as the inoculum (Figure 1). The strain was prepared at an approximate concentration of $10^{5} \mathrm{CFU} / \mathrm{mL}$. Centrifugation of cells was performed at $4500 \times \mathrm{g}$ for 10 min to obtain a cell pellet. Sterilized distilled water was used to rinse the cell pellet before transfer into the bioreactor. 
Malays. J. Microbiol. Vol 14(4) Special Issue 2018, pp. 344-350 DOI: http://dx.doi.org/10.21161/mjm.144188

\section{Fermentation process}

Batch fermentation was performed using a 2-L bioreactor (B. Braun Biotech International, Germany). The fermentation media consisted of $3.7 \%$ HSS and $5 \mathrm{~g} / \mathrm{L}$ of yeast extract. The operating conditions were: temperature $27^{\circ} \mathrm{C}$; agitation $150 \mathrm{rpm}$; initial $\mathrm{pH}$ fixed at $\mathrm{pH} 6.5$, but not controlled. The cells were incubated for 5 days with samples withdrawn daily at $24 \mathrm{~h}$ intervals to determine cell growth (O.D), dry cell weight (DCW), cell viability, residual glucose, and carotenoid concentration (Yehia et al., 2013).

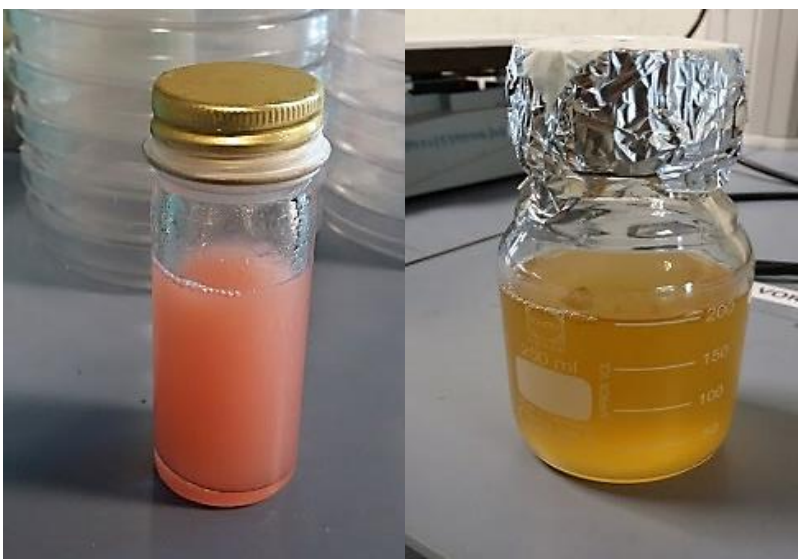

Figure 1: Inoculum preparation ready for performing fermentation.

\section{Measurement of microbial growth}

During batch fermentation, a total of $50 \mathrm{~mL}$ of broth sample was taken to determine optical density, cell viability, dry cell weight and residual glucose. Ten millilitres were taken from the $50 \mathrm{~mL}$ for pigment analysis. The sample was centrifuged for $15 \mathrm{~min}$ at $4500 \times \mathrm{g}$. The supernatant was filtered using $0.45 \mu \mathrm{m}$ filter membrane and stored at $4{ }^{\circ} \mathrm{C}$ for further analysis. The pellet was collected for DCW determination and analysis of pigment.

\section{Optimal density (O.D)}

The growth of yeast was recorded spectrophotometrically by measuring the optical density of yeast growth in the broth at $575 \mathrm{~nm}$ (UV mini-1240, Shimadzu Corporation, Japan).

\section{Dry cell mass (g/L)}

The dry cell weight of yeast was taken as a parameter for its growth. Ten millilitres yeast suspension was centrifuged for $15 \mathrm{~min}$ at $4500 \times \mathrm{g}$, washed twice with distilled water, and finally dried at $105{ }^{\circ} \mathrm{C}$ till constant weight (2-3 h).

\section{Cell viability}

A haemocytometer was used to determine the percentage of living yeast cells using a solution of $0.1 \%(\mathrm{w} / \mathrm{v})$ methylene blue dye. Equal volumes of yeast cell broth and methylene blue solution were mixed in an Eppendorf tube. The percentage of viable cells was counted under the microscope (Painting and Kirsop, 1990).

\section{Reducing sugar}

Dinitro salicylic acid (DNS) method was used to determine the concentration of reducing sugars present in the fermentation broth (Miller, 1959).

\section{Test for carotenoids}

A sample of DCW was mixed with $10 \mathrm{~mL}$ of chloroform in a falcon tube with vigorous shaking. The mixture was filtered using $0.45 \mu \mathrm{m}$ filter membrane. The resulting filtrate was then treated with $85 \% \mathrm{H}_{2} \mathrm{SO}_{4}$. A blue colour interphase indicated the presence of carotenoids in the sample (Ajayi et al., 2011).

\section{Carotenoid extraction and quantification}

Carotenoid extraction was done according to Kanzy et al. (2015), with a sample of $10 \mathrm{~mL}$ taken from the bioreactor (Kanzy et al., 2015). Cells were harvested using centrifugation at $4500 \times \mathrm{g}$ for $15 \mathrm{~min}$.

The supernatant was discharged, while the cell pellet was washed three times with distilled water, then resuspended in $1 \mathrm{~mL}$ of dimethyl sulfoxide (DMSO) preheated to $55^{\circ} \mathrm{C}$. The mixture was vortexed for around $10 \mathrm{sec}$. After centrifugation, the pigment DMSO solution was pipetted off, and the DMSO extraction was repeated three times. The total carotenoid was determined, and optical density was measured using spectrophotometer (UV mini-1 240v, Shimadzu Corporation, Japan) at 501 $\mathrm{nm}$. Total carotenoid content for $R$. mucilaginosa was calculated and expressed as cellular carotenoids $(\mu \mathrm{g} / \mathrm{g}$ dry yeast) and also as volumetric carotenoids (mg/L) of culture. The extinction coefficient $\left(\mathrm{E}_{1 \mathrm{~cm}}{ }^{1 \%}\right) 2040$ was used according to the equation reported by Kanzy et al. (2015). All the operations were performed under subdued light to prevent degradation of pigment.

\section{Data analysis}

The production of pigments from $R$. mucilaginosa was analysed using mean $(\mu)$ of the analysis of the experiment done by duplicate.

\section{RESULTS AND DISCUSSION}

\section{Characteristics of $R$. mucilaginosa}

The colonies grew rapidly, smooth, mucoid and soft. They were orange or pink in colour and hyphae were absent. Figure 2 shows the pigment produced in PDA. Under 
microscopic examination, cell shape was oval with asexual reproduction, showing multi-lateral budding and the absence of ascospores and pseudohyphae.

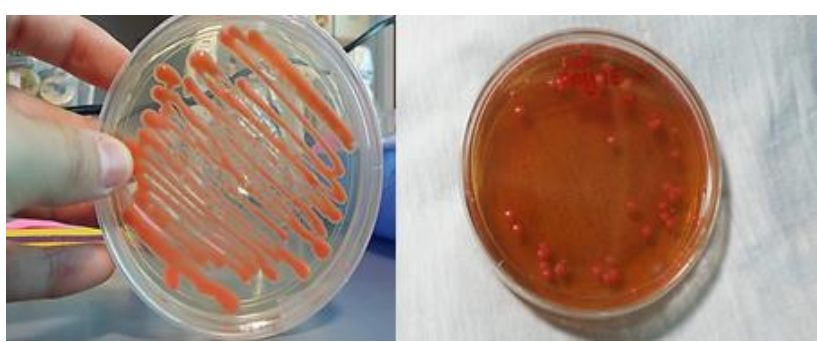

Figure 2: Rhodotorula mucilaginosa cultivated on PDA media at room temperature and used to prepare the inoculum.

\section{Sago starch hydrolysate (SSH)}

The presence of a suitable carbon source is fundamental for the production of carotenoids during the non-growth phase. It is the key for the production of secondary metabolites, various cell structures, and organic chemicals (Moise et al., 2014). Agro-industrial raw materials in many cases result in serious environmental problems. Therefore, the use of sago fibres as a low-cost carbohydrate source could minimize the environmental problem (Aksu and Eren, 2005; Cheng and Yang, 2016). The medium was prepared with $10 \%(\mathrm{w} / \mathrm{v})$ of sago fibres suspension, sufficient to keep the fermentation running properly. Sago fibres containing $55-60 \%$ of starch produced $37.8 \pm 4.4 \mathrm{~g} / \mathrm{L}$ of glucose. Sago fibres served as an excellent raw material to produce glucose, and thus represent an effective alternative and readily manageable option.

\section{Kinetics of cell growth}

Table 1 summarizes the kinetics of the fermentation during the conditions tested. It was observed that fermentation started at DCW of $0.76 \mathrm{~g} / \mathrm{L}$, then grew exponentially during the first $48 \mathrm{~h}$ of the incubation period. The yeast gradually entered the stationary phase during the last three days of incubation. In the stationary phase, the highest OD from $72 \mathrm{~h}$ to $96 \mathrm{~h}$ was 1.014 (OD). Prior to fermentation, the cells were refreshed in universal bottles that contained fresh medium of $20 \mathrm{~g} / \mathrm{L}$ of glucose and 5 $\mathrm{g} / \mathrm{L}$ of yeast extract for $24 \mathrm{~h}$. Then, the cells were transferred to the inoculum medium containing $8 \mathrm{~g} / \mathrm{L}$ of glucose and $1 \mathrm{~g} / \mathrm{L}$ of yeast extract for $12 \mathrm{~h}$ of inoculum. Transferring the cells ensured the cells avoided the long lag phase and accelerated growth during fermentation.

\section{Cell growth}

Dry cell weight (DCW) determination was used to monitor cell growth. Table 1 shows that the initial cell concentration was $0.76 \mathrm{~g} / \mathrm{L}$. DCW continued to increase as cultivation hours progressed. The highest DCW of 9.6 $\mathrm{g} / \mathrm{L}$ was obtained at $96 \mathrm{~h}$. A similar result was reported by Radulescu et al. (2009) where the result of DCW was 9.5 $\mathrm{g} / \mathrm{L}$ at $84 \mathrm{~h}$ (Radulescu et al., 2009). Therefore, the OD and DCW were directly correlated to each other. The overall yield of metabolites was concordant to the total biomass yield. Optimal cultivation conditions are crucial in order to maintain both high flow carbon efficiency to carotenoids and high fermentation growth rates to achieve maximum metabolite productivity (Marova et al., 2011). The data for DCW was used to calculate the specific growth rate $(\mu)$. The $\mu$ of the yeast increased exponentially to $0.130 \mathrm{1} / \mathrm{h}$ in the first $12 \mathrm{~h}$ of incubation period (Table 1). The growth rate continued to increase after $12 \mathrm{~h}$ until it reached the maximum growth rate of $0.181 / \mathrm{h}$ at $48 \mathrm{~h}$. After $48 \mathrm{~h}$, the growth rate of yeasts decreased exponentially to $0.091 / \mathrm{h}$ at $72 \mathrm{~h}$. At $96 \mathrm{~h}$ the cells did not register more growth. When specific growth factors or essential nutrients were exhausted, the cells entered stationary phase. From the data in Table 1, it is observed that cells experienced a faster decrease in overall growth rate when the cells entered stationary phase; therefore, cell proliferation was controlled at this stage.

\section{Cell viability}

Viability represents the survivability of $R$. mucilaginosa cells and was reported as CFU/mL. The percentage was obtained by dividing the number of living cells by the total number of cells. The haemocytometer technique alongside the use of methylene blue dye indicates the presence of an enzyme in a yeast cell, rather than the capability of the cell to divide. Although use of a hemocytometer is less accurate compared to slide count and plate cell count methods, it provides a very useful rapid indication of the number of viable yeast cells compared to traditional plate count methods which provide results only 3 or 4 days after inoculation (Painting and Kirsop, 1990). From Table 1, cell viability (reported as the $\log _{10}$ of $\mathrm{CFU} / \mathrm{mL}$ ) increased as the period of incubation increased. Initial cell concentration started with 4.9 $\mathrm{CFU} / \mathrm{mL}$, then entered exponential growth phase where the viable cells increased to $5.39 \mathrm{CFU} / \mathrm{mL}$ in $48 \mathrm{~h}$, and $5.43 \mathrm{CFU} / \mathrm{mL}$ at $96 \mathrm{~h}$. Entering the plateau or stationary growth phase could be due to a combination of various adverse environmental conditions inhibiting the growth rate of cells. Viable yeast cells contain an enzyme that decolours methylene blue dye. Therefore, they appear as colour-less cells under the microscope. The blue colour was observed in nonviable yeast cells because they do not have the ability to reduce methylene blue dye (Painting and Kirsop, 1990). Table 1 shows the time profile of residual glucose. It is observed that the cells continuously metabolized glucose from the fermentation broth and not all the glucose was consumed, since $13.06 \mathrm{~g} / \mathrm{L}$ of glucose remained when the fermentation was stopped. The percentage of glucose consumption was approximately $65 \%$ of the initial glucose concentration. 
Malays. J. Microbiol. Vol 14(4) Special Issue 2018, pp. 344-350 DOI: http://dx.doi.org/10.21161/mjm.144188

Table 1: Kinetics for the fermentation of hydrolysed sago starch in batch mode.

\begin{tabular}{llllllll}
\hline & & \multicolumn{1}{l}{} & & \multicolumn{2}{l}{ Residual } & \multicolumn{2}{c}{ Productivity of total carotenoids } \\
\hline $\begin{array}{l}\text { Cultivation } \\
\text { time }(\mathrm{h})\end{array}$ & OD & $\mu(1 / \mathrm{h})$ & DCW $(\mathrm{g} / \mathrm{L})$ & CFU $(\log 10)$ & Glucose $(\mathrm{g} / \mathrm{L})$ & Volumetric $(\mathrm{mg} / \mathrm{L})$ & Specific $(\mu \mathrm{g} / \mathrm{g})$ \\
\hline 0 & 0.52 & 0 & 0.76 & 4.91 & 37.67 & 0.44 & 582.00 \\
12 & 0.63 & 0.130 & 1.19 & 5.22 & 34.52 & 0.78 & 663.23 \\
24 & 0.69 & 0.150 & 2.16 & 5.25 & 30.50 & 1.40 & 648.20 \\
36 & 0.80 & ND & 3.96 & 5.26 & 24.02 & 2.64 & 664.61 \\
48 & 1.013 & 0.18 & 8.47 & 5.39 & 20.72 & 6.27 & 739.47 \\
72 & 1.014 & 0.09 & 9.01 & 5.42 & 17.02 & 6.87 & 761.80 \\
96 & 1.014 & 0 & 9.59 & 5.43 & 13.06 & 8.11 & 845.89 \\
\hline
\end{tabular}

\section{Carotenoid assay}

Production of pigment was confirmed by analysing the yeast cell pellets. Figure 3 shows a blue colour interphase appearing after the carotenoid assay was performed, indicating the presence of carotenoids in the sample. To establish the presence of carotenoids, concentrated sulphuric acid was used to produce the characteristic colouration (Karrer and Jucker, 1950). Polyene pigments are best identified by first destroying the surrounding substances, such as fats, before applying the colour tests. The pellet was first treated with concentrated aqueous alcoholic alkali that dissolved the fats and at the same time release the carotenoids within the cells. Chloroform was used as an extractant solvent for fats. Phytoxanthin esters were hydrolysed, and phytoxanthins were liberated. Hence, the presence of carotenoids was shown by a blue colour reaction. Polyene pigments are well known to liberate blue solution when treated with a range of strong acids such as concentrated sulphuric acid. This reaction occurs when a layer of concentrated sulphuric acid is formed under an ethereal solution of pigment. The sulphuric acid layer yielded an intense dark blue to blueviolet colour. Although the colour reactions were not specific, they could be used as qualitative tests (Karrer and Jucker, 1950). Carotenoids have a conjugated double bond system. This produce major problems associated with manipulation and work on carotenoids, especially their instability towards oxygen, heat and light. Acid and alkaline conditions are also detrimental to carotenoids. Degradation, transformation or even change in composition may happen when any of these factors are present in a sample (Oliver and Palou, 2000). Therefore, several precautions were taken.

Manipulations were performed under low light and temperature to avoid direct contact with sunlight. Carotenoid sample preparation and analysis hence required quick work. The pigments were supplemented with butylated hydroxyl toluene (BHT), an antioxidant to increase stability and prevent oxidation (Oliver and Palou, 2000). Finally, the samples were stored in the dark at about $-20^{\circ} \mathrm{C}$ for further analysis whenever necessary.
Before reaction

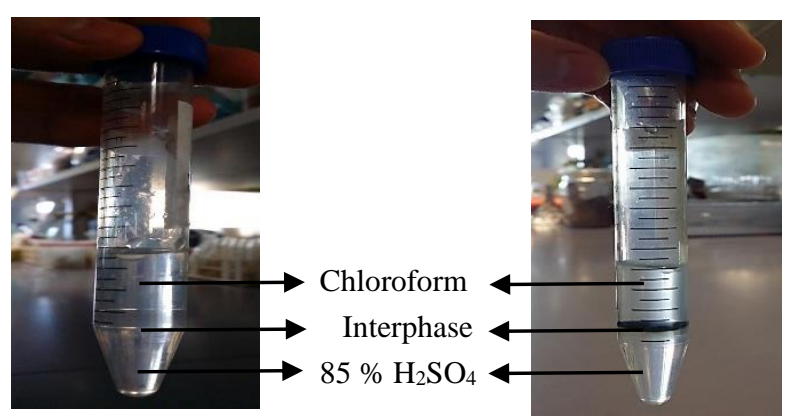

Figure 3: Colour change when the pellet was treated with chloroform and $85 \%$ sulfuric acid. A blue colour interphase indicates the presence of carotenoids.

\section{Carotenoid extraction and quantification}

Secondary metabolism refers to pathways of metabolism that are not essential for the survival of the organism. When nutrients are depleted, Rhodotorula starts to synthesize an array of secondary metabolites (pigments) in order to ensure the survival of cells (Marova et al., 2011). From Figure 4, it is interesting to notice the greater carotenoid pigment accumulations in late logarithmic phase proceeding to stationary phase (starting at $48 \mathrm{~h}$ ). Radulescu et al. (2009) reported total carotenoids of $R$. rubra ICCF 209 obtained using crude extract was 722.23 $\mu \mathrm{g} / \mathrm{g}$ dry cell weight. Similarly, the data in Figure 4 shows that in the $96 \mathrm{~h}$ of cultivation, the highest carotenoid production in $R$. mucilaginosa was $845.89 \mu \mathrm{g} / \mathrm{g}$ dry cell weight. Figure 4 shows the lowest value of dry cell weight and cellular carotenoid, $0.763 \mathrm{~g} / \mathrm{L}$ and $582 \mu \mathrm{g} / \mathrm{g}$ dry yeast respectively, at $0 \mathrm{~h}$. The highest value of dry cell weight was $9.588 \mathrm{~g} / \mathrm{L}$ and highest value of cellular carotenoid yield was $845.89 \mu \mathrm{g} / \mathrm{g}$ dry yeast at $96 \mathrm{~h}$. This shows that the carotenoid yield was directly related to total biomass yield. Therefore, the data obtained suggests that $R$. mucilaginosa is a promising microorganism for commercial carotenoid production using SSH media. One constraint was the complicated liberation and 
bioavailability of carotenoids due to the presence of a thick cell wall (Marova et al., 2013). Therefore, effective and well-characterized techniques of disruption were needed. There were some cellular properties that affect the ease of cellular disruption, requiring varied methods. For example, size or type of cell and the structure of the cell wall. Yeasts synthesize carotenoids when provided with a synthetic medium that contains various simple carbon sources; for example, glucose, sucrose, glycerol, cellobiose, xylose and sorbitol (Marova et al., 2013). DMSO was employed to disrupt the cells in this study due to the previous study has reported that it is efficient to extract carotenoids (Sumanta et al., 2014; Kumar and Keun, 2018).

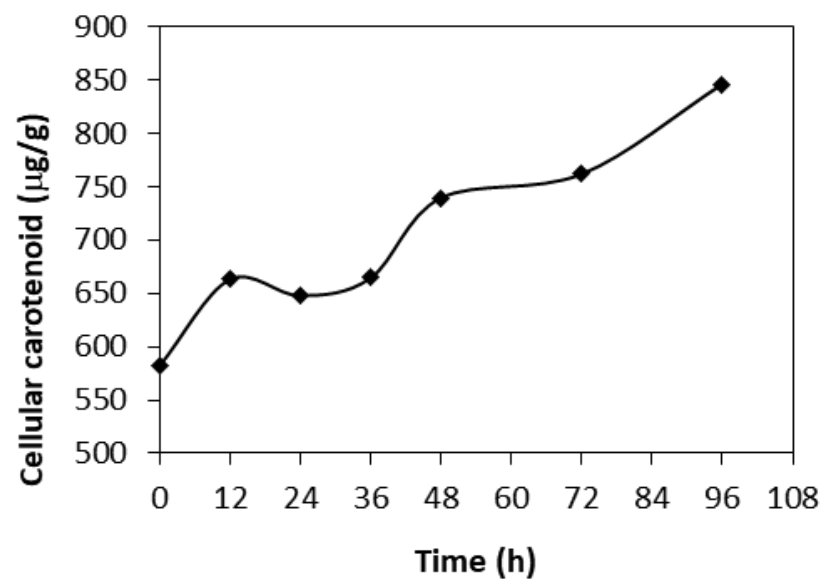

Figure 4: Kinetics of carotenoid production obtained by cells disruption using DMSO.

\section{CONCLUSION}

Rhodotorula mucilaginosa grown on $\mathrm{SSH}$ reached a highest dry cell weight of $9.6 \mathrm{~g} / \mathrm{L}$. The carotenoid produced was $8.11 \mathrm{mg} / \mathrm{L}$ and the specific yield was $845.89 \mu \mathrm{g} / \mathrm{g}$ at $96 \mathrm{~h}$ of cultivation. $R$. mucilaginosa grown at room temperature on substrate derived from sago fibres shows great potential to be an inexpensive and environmentally friendly method for carotenoid production. It could lower the overall cost of production. Bioconversion of sago fibres could be economically valuable for the production of fermentable sugar, while helping to minimise environmental problems associated with agro-residue.

\section{ACKNOWLEDGEMENTS}

The authors would also like to thank UNIMAS and biochemistry laboratory for continuously providing the materials and apparatus for the completion of the project. The project was funded by the grant F02/TOC/1514/2016.

\section{REFERENCES}

Ajayi, I. A., Ajibade, O. and Oderinde, R. A. (2011). Preliminary phytochemical analysis of some plant seeds. Research Journal of Chemical Sciences 1(3), 58-62.

Aksu, Z. and Eren, T. A. (2005). Carotenoids production by the yeast Rhodotorula mucilaginosa: Use of agricultural wastes as a carbon source. Process Biochemistry 40(9), 2985-2991.

Cheng, Y-T. and Yang, C. F. (2016). Using strain to produce carotenoids using food wastes. Journal of the Taiwan Institute of Chemical Engineers 61, 270-275.

Chew, T. Y. and Shim, Y. L. (1993). Sago processing wastes. In: Waste Management in Malaysia: Current Status and Prospects for Bioremediation. Yeoh, B. G. (ed.). Ministry of Science, Technology and the Environment, Kuala Lumpur, Malaysia. pp. 159-167.

Frenova, G. I. and Beshkova, D. M. (2009). Carotenoids from Rhodotorula and Phaffia: Yeasts of biotechnological importance. Journal of Industrial Microbiology and Biotechnology 36(2), 163-180.

Irazusta, V., Nieto-Peñalver, C. G., Cabral, M. E., Amoroso, M. J. and De Figueroa, L. I. C. (2013). Relationship among carotenoid production, copper bioremediation and oxidative stress in Rhodotorula mucilaginosa RCL-11. Process Biochemistry 48(5-6), 803-809.

Joshi, V. K., Attri, D., Bala, A. and Bhushan, S. (2003). Microbial pigments. Indian Journal of Biotechnology 2(3), 362-369.

Kanzy, H. M., Nasr, N. F., El-Shazly, H. A. M. and Barakat, O. S. (2015). Optimization of carotenoid production by yeast strains of Rhodotorula using salted cheese whey. International Journal of Current Microbiology and Applied Sciences 4(1), 456-469.

Karrer, P. and Jucker, P. (1950). Carotenoids. Elsevier, Michigan.

Kumar, R. S. and Keun, Y-S. (2018). Carotenoid extraction methods: A review of recent developments. Food Chemistry 240, 90-103.

Kumoro, A. C., Ngoh, G. C., Hasan, M., Ong, C. H. and Teoh, E. C. (2008). Conversion of fibrous sago (Metroxylon Sagu) waste into fermentable sugar via acid and enzymatic hydrolysis. Asian Journal of Scientific Research 1(4), 412-420.

Lai, J. C., Wan Aizan W. A. R. and Toh, W. Y. (2016). Characterisation of sago pith waste and its composites. Industrial Crops and Products 45, 319326.

Li, M. L., Chi, G. L., Chi, Z., and Chi, Z. M. (2010). Single cell oil production from hydrolysate of cassava starch by marine-derived yeast Rhodotorula mucilaginosa TJY15a. Biomass and Bioenergy 34(1), 101-107.

Linggang, S., Phang, L. Y., Wasoh, M. H. and AbdAziz, S. (2012). Sago pith residue as an alternative cheap substrate for fermentable sugars production. Applied Biochemistry and Biotechnology 167(1), 122131.

Marova, I., Certik, M. and Breierova, E. (2011). Production of enriched biomass by carotenogenic yeasts-Application of whole-cell yeast biomass to production of pigments and other lipid compounds. In: 
Biomass - Detection, Production and Usage. Matovic (ed.). InTech, Rijeka, Croatia. pp. 345-384.

McWilliams, A. (2011). The Global Market for Carotenoids (Report No. FOD025D). BCC Research, Massachusetts, USA.

Miller, G. L. (1959). Use of dinitrosalicylic acid reagent for determination of reducing sugars. Analytical Chemistry (31), 426-428.

Moise, A. R., Al-Babili, S. and Wurtzel, E. T. (2014). Mechanistic aspects of carotenoid biosynthesis. Chemical Reviews 114(1), 164-193.

Oliver, J. and Palou, A. (2000). Chromatographic determination of carotenoids in foods. Journal of Chromatography A 881(1), 543-555.

Olson, J. A. (1964). The biosynthesis and metabolism of carotenoids and retinol (vitamin A). The Journal of Lipid Research 5, 281-299.

Pacia, M. Z., Pukalski, J., Turnau, K., Baranska, M. and Kaczor, A. (2016). Lipids, hemoproteins, and carotenoids in alive Rhodotorula mucilaginosa cells under pesticide decomposition - Raman imaging study. Chemosphere 164, 1-6.

Painting, K. and Kirsop, B. (1990). A quick method for estimating the percentage of viable cells in a yeast population, using methylene blue staining. World Journal of Microbiology and Biotechnology 6(3), 346347.

Radulescu, G., Mocanu, E., Cojocaru, I., Damsa, F., Doncea, S. M. and Ceclan, R. E. (2009). Studies on biosynthetic pathways of obtaining carotenoid pigments. In: Proceedings of the $16^{\text {th }}$ Romanian International Conference on Chemistry and Chemical Engineering, Sinaia, Romania.

Sumanta, N., Haque, C. I., Nishika, J. and Suprakash, R. (2014). Spectrophotometric analysis of chlorophylls and carotenoids from commonly grown fern species by using various extracting solvents. Research Journal of Chemical Sciences 4(9), 63-69.

Yehia, H. M., Al- Olayan, E. M., Elkhadragy, M. F., Khalaf- Allah, A. M. and El- Shimi, N. M. (2013). Improvement of carotenoid pigments produced by Rhodotorula glutinis. Life Science Journal 10(4), 386400.

Yen, H.-W., Liao, Y.-T. and Liu, Y. X. (2016). Cultivation of oleaginous Rhodotorula mucilaginosa in airlift bioreactor by using seawater. Journal of Bioscience and Bioengineering 121(2), 209-212.

Yoo, A., Y., Alnaeeli, M. and Park, J. K. (2016). Production control and characterization of antibacterial carotenoids from the yeast AY-01. Process Biochemistry 51(4), 463-473. 